\title{
Removing elements of nutrition with winter wheat depending on fertilizer and lime in Western Polissia
}

\author{
V.M. Poliovyi ${ }^{1}$, L.A. Yashchenko², N.O. Yuvchyk ${ }^{3}$ \\ Institute of Agriculture of Western Polissia of NAAS \\ 5, Rivnenska Str., Shubkiv, Rivne region, Rivne oblast, 35325, Ukraine \\ e-mail: rivne apv@ukr.net

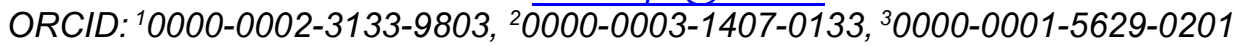

\begin{abstract}
Goal. To determine the content and value of accumulation of nitrogen, phosphorus, and potassium, and to clarify the influence of the removal of elements on the formation of units of the basic and by-products of winter wheat depending on the fertilizing and liming the sod-podzolic bound-sandy soil. Methods. Field, agrochemical, statistical. Results. Aftereffect of the introduction of limestone materials at the systematic application of mineral fertilizers $\left(\mathrm{N}_{120} \mathrm{P}_{60} \mathrm{~K}_{90}\right)$ promotes the increase of the yield of winter wheat grain on $0,6-1,35 \mathrm{t} / \mathrm{ha}$ compared to mineral nutrition and the formation of the ratio of basic products to the side ones on the level of $1.09-1.16$. The highest indicators for the content of products in grain and in straw had the variant with the joint application of $3.8 \mathrm{t} /$ ha of dolomite flour, $\mathrm{N}_{120} \mathrm{P}_{60} \mathrm{~K}_{90}$ with the addition of $\mathrm{S}_{40}$ and 2 times feeding with micro fertilizer Nutrivant Plus Grain (2 kg/ha). The value of elements' removal varied according to the fertilizer systems: for nitrogen in the range of $84.9-130.0 \mathrm{~kg} / \mathrm{ha}$, for phosphorus $-32.3-52.9 \mathrm{~kg} / \mathrm{ha}$, for potassium $-49.5-85.4 \mathrm{~kg} / \mathrm{ha}$. The obtained values allowed to clarify data on the flow of elements per 1 ton of grain and the corresponding volume of straw, which, according to the results of research, made $31.9-34.0 \mathrm{~kg}$ of nitrogen, $11.2-13.7 \mathrm{~kg}$ of phosphorus, and $19.1-22,2 \mathrm{~kg}$ of potassium. Since the by-products did not alienate, the use of the straw made it possible to return into the soil $5.4 \mathrm{~kg} / \mathrm{t}$ of nitrogen, $3.0 \mathrm{~kg} / \mathrm{t}$ of phosphorus, and $12.4 \mathrm{~kg} / \mathrm{t}$ of potassium, which could be used after mineralization for the nutrition of crops in further rotations. Conclusions. The content of basic nutrients in winter wheat harvest to a greater extent varied from fertilizer than the norms of limestone material. This is especially true of nitrogen content in grain and potassium in straw. An increase in the rate of dolomite flour from $3.8 \mathrm{t} /$ ha to $5.7 \mathrm{t} / \mathrm{ha}$ did not significantly influence the arrival of elements to plants. The highest yield of winter wheat grain ( $3.85 \mathrm{t} / \mathrm{ha}$ ) and straw $\left(4.47 \mathrm{t} / \mathrm{ha}\right.$ ) was obtained at entering $\mathrm{N}_{120} \mathrm{P}_{60} \mathrm{~K}_{90}$ in a complex with dolomite flour in the dose of $1 \mathrm{Ng}(3.8 \mathrm{t} / \mathrm{ha})$ and the addition of $S_{40}$ and microelements. Improvement of plant nutrition conditions on the sod-podzolic soil by fertilizer and lime significantly influenced the performance of economic and normative removal of nitrogen, phosphorus, and potassium. The removal of nitrogen (37.1 $105.9 \mathrm{~kg} / \mathrm{ha})$ and phosphorus $(12.1-38.1 \mathrm{~kg} / \mathrm{ha})$ by the grain and potassium $(21.8-58.8 \mathrm{~kg} / \mathrm{ha})$ by the straw had the largest share. The maximum removal of the elements was observed in the variant with the highest yield. The obtained experimental data allowed to specify the doses of nutrient elements per unit of the crop. Since the straw returned to the soil, it is of great interest the normative indicators per 1 ton of basic products, which in the experiment made: for nitrogen $-25.4-27.5 \mathrm{~kg}$, for phosphorus $-8.3-9.9 \mathrm{~kg}$, and for potassium $-5.2-6.9$ $\mathrm{kg}$.
\end{abstract}

Key words: limestone materials, mineral fertilizers, yield, grain, straw, nitrogen, phosphorus, potassium. DOI: https://doi.org/10.31073/agrovisnyk202104-01

The average level of crop yields in modern conditions is $70-80 \%$ of potential, to provide the expected demand for food we need a systematic approach to productivity management based on a quantitative understanding of the response of the crop to nutrients, based on the interaction between the necessary requirements to the nutrient substances of crops and in response to dynamic environmental conditions [1]. The results of research on the peculiarities of the nutrient cycle in the soil-plant-fertilizer system serve as a scientific basis for the development of rational fertilizer systems for crops [2]. In turn, its quantitative and qualitative indicators depend on numerous factors, among which are the zonal features of soil and climatic conditions, the level of fertilizer and agricultural technologies of cultivation [3,4]. During the last 10-15 years, the integration of agriculture is accompanied by significant changes in these factors, which necessitates clarification of the initial parameters for an objective assessment of the balance of nutrients and perfection of crop fertilization systems under the reproduction of soil fertility $[4,5]$.

The basis for determining the expenditure part of the balance is the content and removal of elements by culture. The high variability of data on the removal of nutrients makes problems to use them, so there is a need for research on the optimal content of elements in the grain and straw of winter wheat in specific growing conditions $[6,7]$.

The goal of the research is to identify the specifics of the main nutrients uptake and removal by winter wheat plants depending on fertilization and aftereffect of the different norms and forms of chemical ameliorants on sodpodzolic bound-sandy soil of Western Polissia.

Materials and methods of research. Field research was conducted in a stationary field experiment of the Institute of Agriculture of Western Polissia NAAS. The research crop is winter wheat, which was grown in 20172019 on sod-podzolic bound-sandy soil in crops rotation: winter wheat, corn for grain, spring barley, winter rape. The area of the sown area is $99 \mathrm{~m}^{2}$, the accounting area is $50 \mathrm{~m}^{2}$, the frequency is three times, the placement is consecutive. The cultivation technology is generally accepted for the Polissia zone. 
Mineral fertilizers $\mathrm{N}_{120} \mathrm{P}_{60} \mathrm{~K}_{90}$ were applied according to the experimental scheme in the form of ammonium nitrate, ammophos, and potassium chloride. The norm of chemical ameliorants calculated by soil hydrolytic acidity $(\mathrm{Ha})$ and was applied in 2011 before the establishment of a stationary experiment. In the physical weight of the full norm $\left(1.0 \mathrm{Ha}\right.$ ) corresponded to $4.6 \mathrm{t} / \mathrm{ha}$ of limestone and $3.8 \mathrm{t} / \mathrm{ha}$ of dolomite flour. Nitrogen $\left(\mathrm{N}_{30}\right)$, phosphorus, potassium and sulfur $\left(\mathrm{S}_{40}\right)$ fertilizers were applied under the basic tillage. During the winter wheat growing, which was fed with nitrogen at a dose of $\mathrm{N}_{60}$ during spring tillering and $\mathrm{N}_{30}$ at the beginning of tube emergence. For foliar feeding with microelements (ME) we used the microfertilizer Nutrivant Plus Grain (2 kg/ha) in the appropriate phases.

Analysis of plant material in the air-dry state for the content of nutrients after wet ashing according to Kjeldahl's methods: nitrogen - with Nessler's reagent, phosphorus - photometrically, potassium by flame photometry.

Research results. The degree of reliability of the results of the research of the cycle and balance of nutrients in agriculture primarily depends on the accuracy of the established volumes of their alienation from the soil and income. To calculate the cost of nutrients for the formation of marketable and by-products use indicators of their content in it and the yield [8,9]. The average reference data on the content of elements in the grown crop to establish removal from the soil can differ significantly and affect the reliability of the calculations. The results of research showed that the content of nutrients in both grain and straw of winter wheat significantly changed due to liming and fertilizer (Table 1).

The lowest content of all elements was in the variant without fertilizers. The application of $\mathrm{N}_{120} \mathrm{P}_{60} \mathrm{~K}_{90}$, especially in combination with liming, increased the content of nutrients in the grain by $0.05-0.1 \%$ compared with the control. Significant changes in the content were noted with the addition of the fertilizer system $\mathrm{S}_{40}$ and $\mathrm{S}_{40}+$ microelements in absolute values: for nitrogen $-0.14-0.21 \%$, for phosphorus $-0.13-0.16 \%$, for potassium -0.11 $0.17 \%$. Increasing the amount of dolomite flour to $5.7 \mathrm{t} /$ ha did not significantly affect the content of main elements in the grain compared to the norm of $3.8 \mathrm{t} / \mathrm{ha}$.

1. Nutrient content in winter wheat plants depending on fertilizer and liming, average for 20172019, \% on dry matter

\begin{tabular}{|l|c|c|c|c|c|c|}
\hline \multirow{2}{*}{\multicolumn{1}{|c|}{ Fertilization }} & \multicolumn{3}{c|}{ Grain } & \multicolumn{3}{c|}{ Straw } \\
\cline { 2 - 8 } & $\mathrm{N}$ & $\mathrm{P}_{2} \mathrm{O}_{5}$ & $\mathrm{~K}_{2} \mathrm{O}$ & $\mathrm{N}$ & $\mathrm{P}_{2} \mathrm{O}_{5}$ & $\mathrm{~K}_{2} \mathrm{O}$ \\
\hline Without fertilizers - control & 2.54 & 0.83 & 0.52 & 0.49 & 0.21 & 1.07 \\
\hline $\mathrm{N}_{120} \mathrm{P}_{60} \mathrm{~K}_{90}-$ background (mineral fertilizers $)$ & 2.58 & 0.86 & 0.55 & 0.68 & 0.36 & 1.19 \\
\hline Background $+\mathrm{CaMg}\left(\mathrm{CO}_{3}\right)_{2}(1.9 \mathrm{t} / \mathrm{ha})$ & 2.61 & 0.88 & 0.58 & 0.58 & 0.33 & 1.24 \\
\hline Background $+\mathrm{CaMg}\left(\mathrm{CO}_{3}\right)_{2}(3.8 \mathrm{t} / \mathrm{ha})$ & 2.64 & 0.94 & 0.61 & 0.54 & 0.27 & 1.29 \\
\hline Background $+\mathrm{CaMg}\left(\mathrm{CO}_{3}\right)_{2}(3.8 \mathrm{t} / \mathrm{ha})+\mathrm{S}_{40}$ & 2.68 & 0.96 & 0.63 & 0.56 & 0.32 & 1.35 \\
\hline Background $+\mathrm{CaMg}\left(\mathrm{CO}_{3}\right)_{2}(3.8 \mathrm{t} / \mathrm{ha})+\mathrm{S}_{40}+\mathrm{ME}$ & 2.75 & 0.99 & 0.69 & 0.57 & 0.35 & 1.39 \\
\hline Background $\left.+\mathrm{CaMg}^{*} \mathrm{CO}_{3}\right)_{2}(5.7 \mathrm{t} / \mathrm{ha})$ & 2.62 & 0.91 & 0.62 & 0.52 & 0.26 & 1.17 \\
\hline Background $+\mathrm{CaCO}_{3}(4.6 \mathrm{t} / \mathrm{ha})$ & 2.72 & 0.90 & 0.60 & 0.51 & 0.30 & 1.21 \\
\hline
\end{tabular}

Winter wheat straw was characterized by different, compared to grain, patterns of changes in nutrient content. The highest content of nitrogen and phosphorus, respectively, 0.68 and $0.36 \%$ was observed on the background of $\mathrm{N}_{120} \mathrm{P}_{60} \mathrm{~K}_{90}$. Chemical reclamation of the soil caused a slight decrease in their amount in straw, while the potassium content, on the contrary, increased and reached a maximum value of $1.39 \%$ in the variant $\mathrm{N}_{120} \mathrm{P}_{60} \mathrm{~K}_{90}+1.0 \mathrm{Ha}$ norm of $\mathrm{CaMg}\left(\mathrm{CO}_{3}\right)_{2}+\mathrm{S}_{40}+$ microelements. It is important to note that the increasing of dolomite flour to $1.5 \mathrm{Ha}$ norm did not significantly affect the content of major elements in both grain and straw compared to $1.0 \mathrm{Ha}$ norm. Thus, the difference between the data obtained in the experiment from the average given in the special literature [10], indicates the need for periodic updating of the latter, especially with the specification of growing conditions.

The value of the total alienation of nutrients from the soil is primarily determined by the yield of the main and by-products. Sod-podzolic soils, which dominate in Western Polissia, are characterized by low natural fertility $[11,12]$. The obtained results showed that without the application of ameliorants and mineral fertilizers the grain yield of winter wheat was only $1.46 \mathrm{t} / \mathrm{ha}$ (Table 2). It increased with the application of $\mathrm{N}_{120} \mathrm{P}_{60} \mathrm{~K}_{90}$ to $2.50 \mathrm{t} / \mathrm{ha}$, to the level that is often obtained on chernozem soils without fertilizer $[13,14]$. Thus, the improvement of mineral nutrition is an insufficient measure for competitive cultivation of winter wheat on sod-podzolic soils, which are usually acidic in the reaction of the soil solution $[15,16]$.

\section{Yield of winter wheat depending on fertilization and liming, average for 2017-2019}

\begin{tabular}{|l|c|c|c|}
\hline \multirow{2}{*}{\multicolumn{1}{|c|}{ Fertilization }} & \multicolumn{2}{c|}{ Yield, t/ha } & \multirow{2}{*}{ Ratio } \\
\cline { 2 - 3 } & grain & straw & grain:straw \\
\hline Without fertilizers - control & 1.46 & 2.04 & 1.40 \\
\hline $\mathrm{N}_{120} \mathrm{P}_{60} K_{90}-$ background (mineral fertilizers $)$ & 2.50 & 3.30 & 1.32 \\
\hline Background + CaMg $\left(\mathrm{CO}_{3}\right)_{2}(1.9 \mathrm{t} / \mathrm{ha})$ & 3.10 & 3.38 & 1.09 \\
\hline
\end{tabular}




\begin{tabular}{|l|l|l|l|} 
Background $+\mathrm{CaMg}\left(\mathrm{CO}_{3}\right)_{2}(3.8 \mathrm{t} / \mathrm{ha})$ & 3.46 & 3.88 & 1.12 \\
\hline Background $+\mathrm{CaMg}\left(\mathrm{CO}_{3}\right)_{2}(3.8 \mathrm{t} / \mathrm{ha})+\mathrm{S}_{40}$ & 3.66 & 4.21 & 1.15 \\
\hline Background $+\mathrm{CaMg}\left(\mathrm{CO}_{3}\right)_{2}(3.8 \mathrm{t} / \mathrm{ha})+\mathrm{S}_{40}+\mathrm{ME}$ & 3.85 & 4.47 & 1.16 \\
\hline Background $+\mathrm{CaMg}\left(\mathrm{CO}_{3}\right)_{2}(5.7 \mathrm{t} / \mathrm{ha})$ & 3.80 & 4.14 & 1.09 \\
\hline Background $+\mathrm{CaCO}_{3}(4.6 \mathrm{t} / \mathrm{ha})$ & 3.27 & 3.60 & 1.10 \\
\hline $\mathrm{HIP}{ }_{05} \mathrm{t} / \mathrm{ha}$ & 0.16 & 0.29 & \\
\hline
\end{tabular}

Only a joint application of fertilizers and chemical ameliorants provided a rapid increasing of yield in the experiment. For $\mathrm{N}_{120} \mathrm{P}_{60} \mathrm{~K}_{90}$ in variants with the aftereffect of $1.9 ; 3.8 ; 5.7 \mathrm{t} / \mathrm{ha}$ of dolomite flour the wheat yield was $-3.10 ; 3.46$ and $3.80 \mathrm{t} / \mathrm{ha}$, respectively. The highest it was $3.85 \mathrm{t} / \mathrm{ha}$ with the complex application of $1.0 \mathrm{Ha}$ norm of dolomite flour and $\mathrm{N}_{120} \mathrm{P}_{60} \mathrm{~K}_{90}+\mathrm{S}_{40}+$ two times foliar feeding with microelements.

Compare for the effectiveness of chemical ameliorants, the experiment scheme included a variant with 4.6 $\mathrm{t} / \mathrm{ha}$ of $\mathrm{CaCO}_{3}$. The data showed a $5.81 \%$ higher grain yield with the use of dolomite flour, which is probably due to the presence of magnesium in addition to calcium, which is usually deficient in light soils.

A significant amount of nutrients is alienated from the soil to form plant by-products. The exact establishment of its yield and the content of elements in it significantly affect the objectivity of the indicators of nutrients uptake and balance in general. The results of the research showed that the straw yield changed with the same regularity as the grain, and the highest $4.47 \mathrm{t} /$ ha was with the application $\mathrm{N}_{120} \mathrm{P}_{60} \mathrm{~K}_{90}+\mathrm{S}_{40}+$ microelements by the aftereffect $1.0 \mathrm{Ha}$ norm of dolomite flour.

The yield of by-products per unit area is often determined not by its direct accounting, but by the ratio to the basic, which can vary widely depending on the technology and growing conditions of crops. The results of our research showed that in the variants without fertilizers and with the application of $\mathrm{N}_{120} \mathrm{P}_{60} \mathrm{~K}_{90}$ the widest ratio: 1 : 1.4 and $1: 1.3$, was observed between the grain and straw of winter wheat. The use of fertilizers and limestone materials, regardless of the researched species and norms of ameliorants contributed to the narrowing of the ratio to $1: 1.1-1: 1.2$.

The removal of nutrients with crops is one of the most important agrienvironmental indicators, primarily because it is an important item of their balance and one of the criteria for assessing the degree of soil depletion. The calculations showed that the nitrogen removal by the grain yield of winter wheat without fertilizers was 37.1 $\mathrm{kg} / \mathrm{ha}$, and for $\mathrm{N}_{120} \mathrm{P}_{60} \mathrm{~K}_{90}$ increased more than 1.5 times (Table 3). The application of fertilizers in combination with soil liming, it increased to $80.9-105.9 \mathrm{~kg} / \mathrm{ha}$. The alienation of phosphorus with grain varied in the range of $21.5-38.1 \mathrm{~kg} / \mathrm{ha}$, and potassium - 13.8-26.6 kg/ha. Naturally, the maximum values of these indicators were observed in the variant with the highest yield.

In modern agriculture, almost all by-products are not alienated from the fields. As a result, it has become an extremely important factor on which depends the activity and direction of microbiological processes in soils, the formation of their humus state, nutritional status, and other properties. It increases the relevance of research related to accounting, quality assessment and management of by-products.

When by-products enter the soil, part of the nutrients removed by plants is returned, which reduces the amount of total uptake and therefore requires an accurate determination of its quantity.

As can be seen from the above data, the nutrients removal with wheat straw in the context of the experimental variants varied between $10.0-24.1 \mathrm{~kg} / \mathrm{ha}$ for nitrogen, $4.3-14.8$ for phosphorus and $21.8-58.8 \mathrm{~kg} / \mathrm{ha}$ for potassium. The maximum values of the amount of removal with straw of each of the elements were observed in variant $\mathrm{N}_{120} \mathrm{P}_{60} \mathrm{~K}_{90}+\mathrm{S}_{40}+$ microelements on the background of $1.0 \mathrm{Ha}$ norm of dolomite flour. The largest total uptake of nitrogen, phosphorus and potassium by winter wheat was established under this fertilizer, which amounted to $130.0 \mathrm{~kg} / \mathrm{ha}, 52.9$ and $85.4 \mathrm{~kg} / \mathrm{ha}$, respectively.

Thus, the plowing of winter wheat by-products makes significant changes in the processes of cycle elements, the formation of their balance in the soil, which necessitates the consideration of these factors in the development of crop fertilization systems.

3. Uptake of elements by the harvest of winter wheat depending on fertilization and liming, average for 2017-2019, kg/ha

\begin{tabular}{|c|c|c|c|c|c|c|c|c|c|}
\hline \multirow[b]{2}{*}{ Fertilization } & \multicolumn{3}{|c|}{ Basic products } & \multicolumn{3}{|c|}{ By-products } & \multicolumn{3}{|c|}{ Total uptake } \\
\hline & z & $\overbrace{0}^{\infty}$ & 怘 & $z$ & $\overbrace{0}^{\infty}$ & $\begin{array}{l}\text { O } \\
\text { ִָ }\end{array}$ & $z$ & $\overbrace{n}^{\infty}$ & O \\
\hline $\begin{array}{l}\text { Without fertilizers - } \\
\text { control }\end{array}$ & 37.1 & 12.1 & 7.6 & 10.0 & 4.3 & 21.8 & 47.1 & 16.4 & 29.4 \\
\hline $\begin{array}{l}\mathrm{N}_{120} \mathrm{P}_{60} \mathrm{~K}_{90} \\
\text { background } \\
\text { (mineral fertilizers) }\end{array}$ & 64.5 & 21.5 & 13.8 & 20.4 & 10.8 & 35.7 & 84.9 & 32.3 & 49.5 \\
\hline $\begin{array}{ll}\text { Background } & + \\
\text { CaMg }\left(\mathrm{CO}_{3}\right)_{2} \\
\text { t/ha) }\end{array}$ & 80.9 & 27.3 & 18.0 & 19.8 & 11.3 & 42.3 & 100.7 & 38.5 & 60.3 \\
\hline
\end{tabular}




\begin{tabular}{|c|c|c|c|c|c|c|c|c|c|}
\hline $\begin{array}{l}\text { Background } \\
\text { CaMg( }\left(\mathrm{CO}_{3}\right)_{2} \\
\text { t/ha) }\end{array}$ & 91.3 & 32.5 & 21.1 & 20.6 & 10.3 & 49.1 & 111.9 & 42.8 & 70.3 \\
\hline $\begin{array}{l}\text { Background } \\
\text { CaMg }\left(\mathrm{CO}_{3}\right)_{2} \\
\text { t/ha })+\mathrm{S}_{40}\end{array}$ & 98.1 & 35.1 & 23.1 & 22.6 & 12.9 & 54.4 & 120.7 & 48.0 & 77.5 \\
\hline $\begin{array}{lr}\text { Background } & + \\
\mathrm{CaMg}\left(\mathrm{CO}_{3}\right)_{2} & (3.8 \\
\text { t/ha })+\mathrm{S}_{40}+\mathrm{ME} & \end{array}$ & 105.9 & 38.1 & 26.6 & 24.1 & 14.8 & 58.8 & 130.0 & 52.9 & 85.4 \\
\hline $\begin{array}{l}\text { Background } \\
\text { CaMg( }\left(\mathrm{CO}_{3}\right)_{2} \\
\text { t/ha) }\end{array}$ & 99.6 & 34.6 & 23.6 & 21.7 & 10.9 & 48.9 & 121.3 & 45.4 & 72.5 \\
\hline $\begin{array}{ll}\text { Background } \\
\mathrm{CaCO}_{3}(4.6 \mathrm{t} / \mathrm{ha})\end{array}$ & 88.9 & 29.4 & 19.6 & 18.4 & 10.8 & 43.6 & 107.3 & 40.2 & 63.2 \\
\hline
\end{tabular}

For simplifying of the nutrient's uptake determining of from the soil with the crops can be use literature data of their removal per unit of yield [7, 10]. The obtained experimental data of the main and by-products yield and the accumulation of nitrogen, phosphorus and potassium in the plant's organs allow to clarify the indicators of nutrient removal (Table 4).

Removing 31.9-34.0 kg of nitrogen, $11.2-13.7 \mathrm{~kg}$ of phosphorus and 19.1-22.2 kg of potassium from the soil per 1 ton of grain and the corresponding amount of straw were obtained in experiment. Using of plant's byproducts for fertilizers, the nutrients taken out by it are returned into the soil, so in the calculations of balances it is advisable to consider only their removal by the main products.

4. Normative indicators of nutrients removal of winter wheat depending on fertilization and liming, average for 2017-2019, $\mathrm{kg} / \mathrm{t}$

\begin{tabular}{|l|c|c|c|}
\hline \multicolumn{1}{|c|}{ Fertilizer } & $\mathrm{N}$ & $\mathrm{P}_{2} \mathrm{O}_{5}$ & $\mathrm{~K}_{2} \mathrm{O}$ \\
\hline Without fertilizers - control & $\frac{32.2^{*}}{25.4^{* *}}$ & $\frac{11.2}{8.3}$ & $\frac{20.2}{5.2}$ \\
\hline $\mathrm{N}_{120} \mathrm{P}_{60} \mathrm{~K}_{90}-$ background (mineral fertilizers) & $\frac{34.0}{25.8}$ & $\frac{12.9}{8.6}$ & $\frac{19.8}{5.5}$ \\
\hline Background + CaMg$\left(\mathrm{CO}_{3}\right)_{2}(1.9 \mathrm{t} / \mathrm{ha})$ & $\frac{32.5}{26.1}$ & $\frac{12.4}{8.8}$ & $\frac{19.4}{5.8}$ \\
\hline Background + $\mathrm{CaMg}\left(\mathrm{CO}_{3}\right)_{2}(3.8 \mathrm{t} / \mathrm{ha})$ & $\frac{32.4}{26.4}$ & $\frac{12.4}{9.4}$ & $\frac{20.3}{6.1}$ \\
\hline Background + $\mathrm{CaMg}\left(\mathrm{CO}_{3}\right)_{2}(3.8 \mathrm{t} / \mathrm{ha})+\mathrm{S}_{40}$ & $\frac{33.0}{26.8}$ & $\frac{13.1}{9.6}$ & $\frac{21.2}{6.3}$ \\
\hline Background + $\mathrm{CaMg}\left(\mathrm{CO}_{3}\right)_{2}(3.8 \mathrm{t} / \mathrm{ha})+\mathrm{S}_{40}+\mathrm{ME}$ & $\frac{33.8}{27.5}$ & $\frac{13.7}{9.9}$ & $\frac{22.2}{6.9}$ \\
\hline Background + $\mathrm{CaMg}\left(\mathrm{CO}_{3}\right)_{2}(5.7 \mathrm{t} / \mathrm{ha})$ & $\frac{31.9}{26.2}$ & $\frac{12.0}{9.1}$ & $\frac{19.1}{6.2}$ \\
\hline Background $+\mathrm{CaCO}_{3}(4.6 \mathrm{t} / \mathrm{ha})$ & $\frac{32.8}{27.2}$ & $\frac{12.3}{9.0}$ & $\frac{19.3}{6.0}$ \\
\hline
\end{tabular}

Note: * numerator - per 1 ton of grain and the corresponding amount of straw; ${ }^{* *}$ denominator - per 1 ton of grain.

According to the results of research, the nutrients removal by 1 ton of winter wheat grain in variants varied in the ranges, $\mathrm{kg} / \mathrm{t}:$ 25.4-27.5 for nitrogen, 8.3-9.9 for phosphorus and 5.2-6.9 for potassium. The most fertilizer intensive variant $\mathrm{N}_{120} \mathrm{P}_{60} \mathrm{~K}_{90}+\mathrm{S}_{40}+$ microelements on the background $1.0 \mathrm{Ha}$ of dolomite flour provided the greatest removal of elements both per 1 ton of grain and the corresponding amount of straw and per 1 ton of grain, respectively: 33.8 and $27.5 \mathrm{~kg} / \mathrm{t} \mathrm{N}, 13.7$ and $9.9 \mathrm{P}_{2} \mathrm{O}_{5}, 22.2$ and $6.9 \mathrm{~K} 2 \mathrm{O} \mathrm{kg} / \mathrm{t}$. Using of straw as fertilizer, an average of $5.4 \mathrm{~kg} / \mathrm{t}$ of nitrogen, $3.0 \mathrm{~kg} / \mathrm{t}$ of phosphorus, $12.4 \mathrm{~kg} / \mathrm{t}$ of potassium were returned into the soil, which can be used for nutrition subsequent cultures in crop rotations.

\section{Conclusions}

The content of basic nutrients in the harvest of winter wheat varied to a greater extent from fertilizer than the norm of limestone material. This is especially true of nitrogen in grain and potassium in straw. Increasing the rate of dolomite flour from $3.8 \mathrm{t} / \mathrm{ha}$ to $5.7 \mathrm{t} / \mathrm{ha}$ did not significantly affect the supply of elements to plants. The highest grain yield of winter wheat at the level of $3.85 \mathrm{t} / \mathrm{ha}$ and $4.47 \mathrm{t} / \mathrm{ha}$ of straw was obtained with the application of $\mathrm{N}_{120} \mathrm{P}_{60} \mathrm{~K}_{90}$ in combination with dolomite flour at the rate of $1 \mathrm{Ng}(3.8 \mathrm{t} / \mathrm{ha})$ and the addition of $S_{40}$ and trace elements. Improving the nutritional conditions of the crop on sod-podzolic soil due to fertilization and liming significantly affected the indicators of economic and regulatory removal of nitrogen, phosphorus and potassium. In the economic removal of grain extraction of nitrogen (37.1-105.9 kg/ha) and phosphorus (12.1-38.1 kg/ha) and potassium straw (21.8-58.8 $\mathrm{kg} / \mathrm{ha}$ ) is the largest share. The maximum rates of removal of elements were observed in the variant of the highest productivity. The obtained experimental data allowed to clarify the 
indicators of nutrient removal per unit yield. As straw is returned to the soil, the normative indicators per 1 ton of basic products are of interest, which in the experiment were 25.4-27.5 kg for nitrogen, 8.3-9.9 kg of phosphorus and $5.2-6.9 \mathrm{~kg}$ of potassium.

\section{References}

1. Dobermann, A., \& Cassman, K. (2002). Plant nutrient management for enhanced productivity in intensive grain production systems of the United States and Asia. Plant and Soil, 247, 153 - 175. doi: 10.1023/A:1021197525875

2. Polovyi, V.M. (2007). Optymizatsiia system udobrennia u suchasnomu zemlerobstvi [Optimization of fertilizer systems in modern agriculture]. A monograph. Rivne: Volynski oberehy. [in Ukrainian].

3. Lukashchuk, L.la. (Rivne, December 20, 2012). Intensyfikatsiia tekhnolohii vyroshchuvannia pshenytsi ozymoi - shliakh do zrostannia efektyvnosti zernovoi haluzi [Intensification of technology growing winter wheat is a way to increase the efficiency of the grain industry. Intensification technologies - a way to increase efficiency of agriculture]. (pp. 7-12). Intensyfikatsiia tekhnolohii — shliakh do pidvyshchennia efektyvnosti zemlerobstva: materialy Vseukr. nauk.-prakt. Internet konf. [Materials All-Ukrainian. Science practice. Internet conf]. Rivne. URL: http://www.isg.rv.ua/images/files/Konference_2012_12_20.pdf [in Ukrainian].

4. Baliuk, S.A., Nosko, B.S., Shymel, V.V. et al. (2019). Optymizatsiia zhyvlennia roslyn u systemi faktoriv efektyvnoi rodiuchosti gruntiv [Optimization of plant nutrition in the system of factories of effective soil fertility]. Herald agricultural science, 3, 12-19. doi: 10.31073/agrovisnyk201903-02 [in Ukrainian].

5. Zaryshniaka, A.S. (Ed.). (2015). Optymizatsiia udobrennia ta rodiuchosti gruntu $v$ sivozminakh [Optimization of fertilizers and soil fertility that in crop rotations]. Kyiv: Ahrarna nauka. [in Ukrainian].

6. Hospodarenko, H.M., Cherno, O.D., \& Liubych, V.V. (2020). Zasvoiennia osnovnykh elementiv zhyvlennia z gruntu y mineralnykh dobryv pshenytseiu ozymoiu na chornozemi opidzolenomu Pravoberezhnoho Lisostepu Ukrainy. [Assimilation of basic nutrients from the soil and mineral fertilizers with winter wheat on black nozemy podzolic Right-Bank Forest-Steppe of Ukraine]. Bulletin of Agrarian Science of the Black Sea Region, 3, 35-44. doi: 10.31521/2313-092X/2020-3(107) [in Ukrainian].

7. Tyler, G., \& Olsson, T. (2001). Plant uptake of major and minor mineral elements as influenced by soil acidity and liming. Plant and Soil, 230, 307-321 doi: 10.1023/A:1010314400976

8. Ivanina, R.V. (2019). Vynos ta balans elementiv zhyvlennia v zernovykh lankakh sivozminy za riznykh system udobrennia [Removal and balance of nutrients in grain units of crop rotation under different systems fertilizer topics]. Scientific reports of NULES of Ukraine, 6 (82). doi:10.31548/dopovidi2019.06.011 [in Ukrainian].

9. Hrekov, V.O., Datsko, L.V., Zhylkin, V.A. et al. (2011). Metodychni vkazivky z okhorony gruntiv [Methodical instructions on soil protection]. Kyiv. [in Ukrainian].

10. Baliuk, S.A., Hrekov, V.O., \& Lisovyi, M.V. (2011). Rozrakhunok balansu humusu i pozhyvnykh rechovyn u zemlerobstvi Ukrainy na riznykh rivniakh upravlinnia [Calculation of the balance of humus and nutrients in agriculture of Ukraine at different levels of government laziness]. Kharkiv: KP «Miska drukarnia». [in Ukrainian].

11. Polovyi, V.M., Lavruk, M.M., \& Kulyk, C.M. (2018). Dyferentsiatsiia fizyko-khimichnykh pokaznykiv i produktyvnosti dernovo-pidzolystoho gruntu vnaslidok tryvaloho zastosuvannia riznykh system udobrennia i doz vapna [Differentiation of physicochemical parameters and productivity of sod-podzolic soil due to long-term use of different systems topics of fertilizer and doses of lime]. Bulletin of Agricultural Science, 5 (782), 12-17. doi: 10.31073/agrovisnyk201805-02 [in Ukrainian].

12. Pashkova, M.V. (2019). Produktyvnist pshenytsi ozymoi na osushuvanykh dernovo-pidzolystykh gruntakh Volynskoho Polissia zalezhno vid system udobrennia ta temperaturnoho rezhymu [The productivity of winter wheat mine on drained sod-podzolic soils Volyn Polissya depending on fertilizer systems and temperature]. Melioration and water management 1, 61 - 66. doi: 10.31073/mivg201901168 [in Ukrainian].

13. Hospodarenko, H.M., \& Yeshchenko, N.B. (2013). Urozhainist pshenytsi ozymoi na chornozemi opidzolenomu Pravoberezhnoho Lisostepu zalezhno vid riznykh vydiv i norm dobryv ta yikh okupnist: zb. nauk. prats Umanskoho natsionalnoho universytetu sadivnytstva. [Gospodarenko GM, Yeshchenko NB Uroharvest of winter wheat on chernozem right-bank Forest-Steppe depending on different types and rates of fertilizers and their payback: Coll. Science. works of Uman National University gardening site]. Uman, 82(1), 8-14. [in Ukrainian].

14. Halysh, F.S. (2007). Udobrennia pshenytsi ozymoi v Zakhidnomu Lisostepu. Zb. nauk. Prats Natsionalnoho naukovoho tsentru «Instytut zemlerobstva NAAN» [Fertilizers of wheat winter mine in the Western Forest-Steppe]. Coll. Science. National Research Center "Institute Agriculture NAAS", 3-4, 16 - 21. URL: http://nbuv.gov.ua/UJRN/znpzeml_2007_3-4_5. [in Ukrainian].

15. Polovyi, V. M., Lukashchuk, L. Ya., \& Lavruk, M. M. (2012). Reaktsiia pshenytsi ozymoi na udobrennia zalezhno vid kyslotnosti dernovo-pidzolystoho gruntu [The reaction of winter wheat to fertilizers but from the acidity of sod-podzolic soil]. Bulletin of Agricultural Science, 12, 18 - 21. URL: http://nbuv.gov.ua/UJRN/vaan_2012_12_5. [in Ukrainian].

16. Savchuk, O.I., Hurelia, V.V., Melnychuk, A.O. et al. (Zhytomyr, May 19, 2018). Osoblyvosti zemlekorystuvannia silskohospodarskykh uhid zony Polissia v umovakh zmin klimatu. Suchasnyi stan $i$ perspektyvy efektyvnoho vykorystannia zemelnykh resursiv Polissia (pp. 115 - 119). Materialy naukovopraktychnoi konferentsii [Features of agricultural land use economic lands of the Polissya zone in the conditions of changes climate. The current state and prospects of effective use of land resources of 
Polissya: materials of the scientific-practical conference]. Zhytomyr: Vydvo ETs «Ukrekobiokon». URL:www.iogu.gov.ua/wp-content/uploads/2019/05/ZBIRNYK-STATEI-ISHP-2018.pdf [in Ukrainian]. 